Przegląd Prawa Konstytucyjnego

-----ISSN 2082-1212-----

DOI 10.15804/ppk.2018.02.14

-----Nr $2(42) / 2018-----$

\title{
Sprawozdanie
}

\section{Dyskusja panelowa Reforma wymiaru sprawiedliwości, Okręgowa Rada Adwokacka w Szczecinie, Szczecin, 19 września 2017 r.}

19 września 2017 r. w siedzibie Szczecińskiej Okręgowej Izby Adwokackiej odbyła się dyskusja panelowa poświęcona reformie wymiaru sprawiedliwości. Spotkanie zorganizowali wspólnie Rzecznik Praw Obywatelskich dr Adam Bodnar, Okręgowa Izba Adwokacka w Szczecinie oraz Redakcja Miesięcznika Szczecińskich Środowisk Prawniczych „InGremio”.

W spotkaniu udział wzięli przedstawiciele szczecińskich środowisk prawniczych i świata nauki. W panelu dyskusyjnym, pod przewodnictwem dra Adama Bodnara, udział wzięli SSR Olimpia Barańska-Małuszek, dr hab. prof. US r. pr. Jerzy Ciapała, Prezes Sądu Apelacyjnego w Szczecinie SSA Maciej Żelazowski oraz Dziekan ORA w Szczecinie adw. Włodzimierz Łyczywek.

Jako pierwszy głos zabrał prof. Jerzy Ciapała, który skoncentrował się na zagadnieniu konstytucyjności ustawy z 12 lipca 2017 r. o zmianie ustawy Prawo o ustroju sądów powszechnych ${ }^{1}$. Prelegent wskazał, że w ustawie tej znajduje się co najmniej 6 przepisów (regulacji) budzących uzasadnione wątpliwości co do ich zgodności z Konstytucją Rzeczypospolitej Polskiej z 2 kwietnia 1997 r. ${ }^{2}$ Są to m.in. zakres niezawisłości i niezależności asesorów sądowych mających sprawować wymiar sprawiedliwości, pozycja prawna dyrektora sądu (rozpatrywana w relacji z Ministrem Sprawiedliwości i prezesem sądu,

Dz.U. poz. 1452.

2 Dz.U. Nr 78, poz. 483 ze zm., zwana dalej „Konstytucją RP”. 
w którym dany dyrektor pełni funkcję), a także kompetencje Ministra Sprawiedliwości do powoływania prezesów sądów powszechnych z pominięciem udziału czynnika sędziowskiego.

Prelegent jednocześnie podkreślił, że wątpliwości co do konstytucyjności budziły również dwie ustawy zawetowane przez Prezydenta Rzeczypospolitej Polskiej 24 lipca 2017 r., tj. ustawa z 20 lipca 2017 r. o zmianie ustawy o Sądzie Najwyższym ${ }^{3}$ oraz ustawa z 12 lipca 2017 r. o zmianie ustawy o Krajowej Radzie Sądownictwa ${ }^{4}$. Odnosząc się w szczególności do drugiej z tych ustaw, prelegent wskazał, że w świetle przepisów art. 187 Konstytucji RP Krajowa Rada Sądownictwa (dalej zwana „KRS”) nie jest organem samorządu sędziowskiego, lecz pełni rolę organu wspierającego władzę sądowniczą. Jej aktualne usytuowanie prawne, w tym kompetencje i struktura, a także sposób wyboru składu, są optymalne z punktu widzenia realizacji norm konstytucyjnych. Niedopuszczalny zaś jest przewidziany zawetowaną ustawą podział tego organu na dwie izby, z których jedna miałaby charakter polityczny, a druga - sędziowski. Ustrojodawca przewidział - zdaniem prelegenta, podpartym poglądami doktryny - jedynie możliwość określenia preferencji co do liczby sędziowskich członków tego organu, wywodzących się z sądów poszczególnych szczebli sądownictwa. Opisując europejskie modele rad sądowniczych, prelegent wskazał, że konstytucyjnie niedopuszczalny byłby wybór sędziów do KRS przez Sejm, nawet gdyby dojść do niego miało większością kwalifikowaną 2/3 głosów.

Jako drugi głos zabrał SSA Maciej Żelazowski. Prelegent przewrotnie wskazał na pozytywną stronę grupy ustaw, poczynając od ustawy z 18 sierpnia 2011 r. o zmianie ustawy Prawo o ustroju sądów powszechnych ${ }^{5}$, po wskazane wyżej trzy ustawy Sejmu VIII kadencji. Dzięki nim doszło do niespotykanej dotychczas w Polsce integracji społeczeństwa wokół sędziów i władzy sądowniczej. Zdaniem prelegenta, ustawa o zmianie ustawy o KRS, czytana w oderwaniu od dwóch zawetowanych ustaw, może być błędnie oceniana jako mniej wadliwa, aniżeli powszechnie się o niej sądzi. Jej analiza wskazu-

3 Por.http://www.prezydent.pl/prawo/ustawy/zawetowane/art,5,prezydent-ustawy-okrs-i-sn-do-ponownego-rozpatrzenia-przez-sejm.html (20.09.2017).

4 Por.http://www.prezydent.pl/prawo/ustawy/zawetowane/art,4,prezydent-przekazalsejmowi-do-ponownego-rozpatrzenia-ustawe-o-krs.html (20.09.2017).

Dz.U. Nr 203, poz. 1192. 
je, że wykonywanie przez Ministra Sprawiedliwości kompetencji wobec sądów powszechnych znajduje się pod kontrolą KRS, która może sprzeciwić się decyzji ministerialnej. Taka interpretacja jest jednak - zdaniem prelegenta wadliwa, bo nie uwzględnia faktu, że zawetowana ustawa o zmianie ustawy o KRS zakładała całkowitą wymianę składu sędziowskiego tego organu i w efekcie podporządkowanie go (dzięki wyborom przez Sejm) aktualnej większości parlamentarnej, co w konsekwencji czyniłoby prawo sprzeciwu KRS kompetencją fasadową. Nie sposób uwierzyć, że KRS o składzie ukształtowanym przez większość parlamentarną sprzeciwiłaby się działaniom podjętym przez polityka wywodzącego się z tejże większości.

Prelegent wskazał nadto, że budzi uzasadnione wątpliwości (w kontekście ochrony niezawisłości sędziowskiej) nader znaczące usamodzielnienie pozycji dyrektora sądu połączone z immanentnym związaniem go z Ministrem Sprawiedliwości, np. poprzez to, że Minister ów decyduje o powołaniu i odwołaniu dyrektora danego sądu, bez konieczności przeprowadzenia procedury konkursowej przewidzianej dotychczasowymi przepisami.

Prelegent wskazał, że nader niebezpieczną sytuacją dla całego państwa jest to, że samo państwo podważa jeden ze swych filarów. Trwająca propagandowa kampania skierowana przeciwko władzy sądowniczej, a inicjowana przez większość rządową (co oczywiste - dzierżącą arkana władzy wykonawczej i ustawodawczej), ma przydać tejże większości argumentów za reformą, a w zasadzie ubezwłasnowolnieniem, władzy sądowniczej. Rzutuje to w sposób istotny nie tylko na niezależność sędziów, lecz również podkopuje filary samego państwa, zagrażając jego pomyślnemu bytowi.

Jako kolejna głos zabrała SSR Olimpia Barańska-Małuszek. Prelegentka zauważyła, że masowe wsparcie społeczeństwa, jakie otrzymali w ostatnim roku sędziowie, pozwoliło tej grupie zawodowej na dostrzeżenie, że w pełnieniu swej funkcji nie są „sfinksami”, wydającymi orzeczenia i za ich pośrednictwem komunikującymi się ze społeczeństwem, lecz że mają prawo i obowiązek publicznego zabierania głosu w sprawach władzy sądowniczej. Postępujący wzrost świadomości sędziów i postępująca (naturalna) wymiana pokoleniowa sprawiły, że sędziowie chçą aktywnie uczestniczyć w życiu publicznym wspólnoty w celu pogłębienia społecznego zaufania do trzeciej władzy. Aby im to ułatwić, konieczne są zmiany w najbardziej elementarnych przejawach ich działalności. Sędziowie winni w swej codziennej pracy na sali 
sądowej być bardziej komunikatywni i zrozumiali do uczestników postępowania, niebędących prawnikami; powinni mówić zrozumiałym językiem i okazywać empatię. Domaga się tego samo społeczeństwo, które po przystąpieniu Polski do Unii Europejskiej poznało inne kultury prawne i chce wywiedzione z nich pozytywy zaszczepić na polskim gruncie. Aby jednak utrzymać wzrost zaufania społeczeństwa do sędziów i władzy sądowniczej, nie można dopuścić do przyjmowania regulacji prawnych, które doprowadzą do podważenia wiarygodności sędziów. Przykładem takiej regulacji jest - zdaniem prelegentki - powierzenie prezesom sądów kompetencji do obsadzania dyżurów aresztowych, co może być wykorzystywane - jak uczy doświadczenie lat 80 . XX w. - do wyznaczania na dane terminy sędziów o określonych optykach widzenia określonych kategorii spraw.

Jako ostatni głos zabrał jeden z gospodarzy spotkania - Dziekan ORA w Szczecinie adw. Włodzimierz Łyczywek, który postawił fundamentalne dla prowadzonych rozważań pytanie - czy reforma wymiaru sprawiedliwości jest w ogóle potrzebna? Wszak od stuleci mówi się, że sądy wymagają reformy, a samo to stwierdzenie nie przesądza jednak o rzeczywistej potrzebie podjęcia określonych działań. Nie jest dopuszczalne, zdaniem prelegenta, aby sądy zostały zmajoryzowane przez czynniki polityczne. Jednym z zabezpieczeń przed taką sytuacją jest skonstruowanie zawodu sędziego, jako „korony zawodów prawniczych”. Zbyt młodzi ludzie powoływani na urząd sędziego albo asesora sądowego nie dysponują ani doświadczeniem zawodowym, ani tym bardziej doświadczeniem życiowym, legitymującym do oceny postępowań innych. Zdaniem prelegenta, proponowane zmiany nie mają w rzeczywistości doprowadzić do reformy wymiaru sprawiedliwości zmierzającej do ideału sprawnych i efektywnych postępowań sądowych. Gdyby tak było, to nie rozważano by zagadnień podporządkowania wymiaru sprawiedliwości Ministrowi Sprawiedliwości, lecz rozważono by konieczność obsadzenia wolnych etatów sędziowskich, zmiany w zakresie zasad ponoszenia i wysokości opłat sądowych, czy uproszczenia procedur. Prowadzona kampania informacyjna, choć jest obrzydliwa z punktu widzenia moralnego, odnosi skutki i wzmaga poparcie dla szkodliwych i nieprzemyślanych reform.

Zgodnie z przyjętym porządkiem spotkania, po wolnych wystąpieniach prelegentów otworzona została dyskusja $\mathrm{z}$ udziałem publiczności. W jej trakcie wskazano, że reforma wymiaru sprawiedliwości nie może dotyczyć wy- 
łącznie sędziów, bo konieczne jest skonstruowanie nowej regulacji dotyczącej podmiotów wspomagających wymiar sprawiedliwości, tj. biegłych sądowych. Choć od lat projektowane są stosowne przepisy ich dotyczące, to prace nie mogą się zakończyć i nie dotyczą (jak dotąd) jednego z podstawowych zagadnień, jakim jest sposób ustalania i wysokość należnego biegłym sądowym wynagrodzenia.

Nadto w dyskusji wskazano, że na przestrzeni dwóch ostatnich dziesięcioleci nie było w Polsce - mimo szumnych deklaracji - rzeczywistej reformy wymiaru sprawiedliwości, lecz jedynie następowały zmiany struktury sądownictwa, połączone z nieustannymi próbami zwiększenia politycznego wpływu na sędziów. Rzeczywista reforma powinna polegać na uproszczeniu procedur tak, aby kwestie o charakterze proceduralnym nie przesądzały o bezpotrzebnym przedłużaniu postepowania. Dyskutanci zgodnie stwierdzili, że nie może dojść do rzeczywistej, pożądanej reformy sądów (co do potrzeby której nie ma wątpliwości), bo nie przyniesie ona wzrostu poparcia politycznego dla jej ewentualnych twórców. Stąd pasywność polityków i brak poparcia dla realnej reformy.

Dyskutanci nie zgodzili się z tezą, że - wobec stanu wyższej konieczności państwowej - sądy powszechne i Sąd Najwyższy winny zabrać głos w wymiarze politycznym. Na tym polega, zdaniem dyskutantów, niezależność sądów i niezawisłość sędziowska, że niezależnie od żywionych przez indywidualnych sędziów poglądów politycznych (które jak każdy światły obywatel posiadają) i sytuacji politycznej państwa, orzekają i będą orzekać na podstawie prawa, zgodnie ze swym sumieniem, doświadczeniem i wiedzą. Inne pojmowanie funkcji sędziego byłoby ostatecznym upadkiem judykatury.

Dyskutanci wskazali również na wadliwość przyjętego modelu szkolenia przyszłych sędziów w ramach Krajowej Szkoły Sądownictwa i Prokuratury. Podmiot ten wpaja swym adeptom, zamiast etosu zawodowego i pożądanych postaw zawodowych, bezrefleksyjne podporządkowanie Ministrowi Sprawiedliwości.

Zwrócono również uwagę na to, że prawdziwa reforma wymiaru sprawiedliwości może się powieść jedynie wtedy, gdy z jej postulatami i założeniami uda się dotrzeć do społeczeństwa, w którego interesie będzie ona przeprowadzona i które jest ostatecznym podmiotem dokonującym rozrachunku i oceny funkcjonowania trzeciej władzy. 
Z poglądów przedstawionych przez uczestników panelu wynika, że zagadnienie reformy wymiaru sprawiedliwości winno być rozważane w trzech powiązanych ze sobą, lecz wyodrębnianych dla zachowania klarowności rozważań, aspektach. Po pierwsze, w aspekcie ustalenia rzeczywistej potrzeby przeprowadzenia reformy wymiaru sprawiedliwości, dokonania oceny obszarów wymagających zmian i ich pożądanych kierunków. Po drugie, zgodności proponowanych zmian ze standardami konstytucyjnymi. Po trzecie, efektywności proponowanych zmian w kontekście ich przydatności (na gruncie posiadanej wiedzy i doświadczenia) do rzeczywistego usprawnienia funkcjonowania wymiaru sprawiedliwości. Aspekty te są ze sobą immanentnie powiązane. Nie sposób sensownie rozważać reformy wymiaru sprawiedliwości bez uwzględnienia wszystkich $\mathrm{z}$ nich.

Podnoszone wątpliwości i przedstawiane uwagi nie przeszkodziły prelegentom i dyskutantom w osiągnięciu powszechnej zgody, że wymiar sprawiedliwości wymaga reform, lecz nie takich, jak obecnie forsowane.

Jan Uniejewski Uniwersytet Szczeciński 